\title{
Portretējot ienaidnieku: Rīgas kinostudijas spēlfilmas par Rietumu sabiedrību ${ }^{1}$
}

\author{
Portraying the Enemy: Feature Films of Riga Film Studio on \\ Western Society
}

\author{
Toms Zariṇš, Mg. hist. \\ Frīdriha Eberta fonda (Friedrich-Ebert-Stiftung) Latvijas biroja projektu vadītājs \\ Dzirnavu iela 37-64, Rīga, LV-1010 \\ E-pasts: tomszarins2@gmail.com
}

Desmit gadu laikā - no 20. gadsimta 70. gadu vidus līdz 80. gadu vidum - Rīgas kinostudijā tika uzṇemtas vairākas specifiskas spēlfilmas "televīzijas mākslas filmas", kuru darbība pilnībā norisinās "kapitālistiskajos Rietumos" un kuras vieno kopīgas pazìmes, kas nebija raksturīgas citām padomju kinofilmām. Raksta mērķis ir norādīt uz šai filmu grupai raksturīgajām pazīmēm un izskaidrot šo filmu tapšanas ìpatnības. Tēmas izpētē secināts, ka spēlfilmas par Rietumu sabiedrību bija vienota, īpatnēja aukstā kara parādība, kas sevī iemiesoja starptautiskās politikas, padomju ideoloğisko nostādṇu un kinematogrāfijas tendenču sajaukumu.

Atslēgvārdi: Padomju Savienība, Latvijas PSR, aukstais karš, kinematogrāfija, televīzija, propaganda, Rīgas kinostudija.

Within a decade - from the mid-1970s to the mid-1980s - Riga Film Studio produced a series of specific films, i.e., several television film series set entirely in 'capitalist West'. No other Soviet film had the characteristics present in the abovementioned category. The aim of the article is to illuminate the common features inherent to this particular group of films and to examine the specifics of their production. During the preliminary research, it was concluded that the films about the Western society was a rather peculiar Cold War phenomenon that embodied a mixture of international politics, fundamental soviet ideological principles and tendencies of cinematography.

Keywords: Soviet Union, Latvian SSR, Cold War, cinematography, television, propaganda, Riga Film Studio.

20. gadsimta 70. un 80. gados Rīgas kinostudijā (RKS) tika uzņemtas specifiskas spēlfilmas - tās bija vairākas "televīzijas mākslas filmas", kuru sižeta darbība pilnībā norisinās "kapitālistiskajos Rietumos". Tām piemita savrupi nodalāmas pazīmes, kuras nebija 
raksturīgas citām šì perioda padomju spēlfilmām - uz ārvalstu autoru literāriem pirmavotiem balstīti scenāriji, sižeta darbība Rietumos un Rietumu sabiedrības pārstāvju tēli visu darbojošos personu lomās. Būtiska atšķirība pastāvēja arī šo filmu uzdevumos, kur līdzās izklaidēšanai šīm filmām bija jāpilda arī ideologiska "kontrpropagandas" jeb Rietumu dzīvesveidu diskreditējošas padomju propagandas funkcija. Vairākos gadijumos šādas filmas tika uzņemtas arī citās Padomju Savienības kinostudijās, taču vienīgi RKS gadījumā šīs filmas veido daudzskaitlīgu grupu.

Minētās spēlfilmas, kuru sižeta darbība pilnībā norisinās Rietumos, ir maz pētītas. Populārākās no tām - "Mirāža" (1983) un "Nepabeigtās vakariņas" (1979) - galvenokārt aplūkotas kino vēstures pētījumos Latvijas nacionālās kinematogrāfijas un autoru daiḷrades kontekstā. Dažās publikācijās, kā, piemēram, žurnālistes Kristīnes Matīsas grāmatā "Vecās labās... 50 latviešu kinoklasikas spožākās pērles"² un kinozinātnieces Ingas Pērkones sarakstītajās nodaḷās grāmatā "Inscenējumu realitāte. Latvijas aktierkino vēsture" ${ }^{3}$ ir aplūkota arī šo filmu tapšanas gaita vai noteikti filmu satura elementi, tomēr nav sīkāk pētīta filmu "kontrpropagandas" funkcija. Mazāk zināmās šîs grupas filmas - "Nāve zem buras" (1976), "Pēdējā vizīte" (1984) un "Pēdējā reportāža" (1986) - nav aplūkotas nevienā no minētajiem pētniecības virzieniem.

Autora veiktā izpēte ieklaujas pēdējo gadu pētnieciskajā tendencē - saskaṇā ar to aukstā kara pētniecībā būtiska ir ne tikai līdz šim dominējošā augstākā līmeṇa politikas un starptautisko attiecību analīze, bet arī zemāku darbības līmeṇu un aktoru pētniecība. ${ }^{4}$ Aukstais karš dal̦ēji tika realizēts ar vārdu un tēlu palīdzību: četrdesmit gadus ilgajā cinnā starp Rietumiem un padomju bloku pašā uzmanības centrā bija propaganda dažādos līmeños un daudzveidīgās izpausmēs - abpusēja informācijas kara ieroči bija mūzika, dejas māksla, kinematogrāfija, dizains, vārdu un tēlu radīšana un izplatīšana. ${ }^{5}$ Rietumu pētnieki uzskata, ka kultūras aktivitātēm bija centrālā loma ideologiskajā sacensībā un tās noteikušas aukstā kara uztveri daudziem cilvēkiem. ${ }^{6}$

Rakstā ir lietoti jēdzieni, kuriem nepieciešams skaidrojums. Galvenais no tiem "kontrpropaganda" - ir specifisks padomju apzīmējums. Literatūrzinātniece Eva EglājaKristsone savā pētījumā par t. s. "kultūras sakariem" konstatējusi, ka "padomju propagandu, kas [bija] vērsta pret emigrāciju, padomju varas un drošǐbas iestādes dēvēja par kontrpropagandu". ${ }^{7}$ Šajā rakstā jēdziens "kontrpropaganda" pilnībā lietots tā padomju perioda nozīmes kontekstā, kad ar to saprata "buržuāziskās ideoloğijas atmaskošanu kā vienu no svarīgākajiem komunistiskās propagandas uzdevumiem". ${ }^{8}$ Savukārt ar jēdzienu "mākslas filma" rakstā saprasta tāda filma, kuras pamatā ir inscenēts sižets; šis pētāmajā periodā pienemtais spēlfilmu apzīmējums tekstā lietots paralēli atbilstošajiem mūsdienu jēdzieniem "spēlfilma", "aktierfilma" un "aktierkino". ${ }^{9}$ Atsevišķi nodalāms arī jēdziens "televīzijas mākslas filma" - 70. gados tika aktivizēts un ar ekonomiskās plānošanas instrumentu palīdzību laika gaitā institucionalizēts jauns kinofilmu ražošanas veids. Tās bija pēc PSRS Valsts televīzijas un radioraidījumu komitejas radošās apvienības Ekran pasūtījuma kinostudijās uzṇemtas spēlfilmas, kurās īpaša uzmanība pievērsta scenāriju un vizualitātes risinājumam atbilstoši perioda "televizioniskuma" estētiskajiem principiem (lakoniska vizualitāte, vidējo plānu un tuvplānu pārsvars), piemērojot tās primārai izrādīšanai Maskavas Centrālajā televīzijā. Pēdējā apsvēruma dēḷ RKS iekšējā saziṇā filmu formālais pasūtītājs - r/a Ekran - tika apzīmēts kā Centrālā televīzija (CT), un šāda kārtība saglabāta arī turpmāk tekstā.

Turpmākajās trīs raksta apakšnodalāās izklāstìts starptautiskās politikas, padomju 
ideologisko nostādṇu un padomju kultūras procesu konteksts, kas l,āva rasties šāda specifiska veida spēlfilmām, kurās atveidoti Rietumi, bet pēdējā apakšnodaḷā aprakstītas šādu filmu tapšanas īpatnības Rīgas kinostudijā.

\section{Starptautiskā politika - padomju "kontrpropagandas" augsne}

20. gadsimta 60. gadu beigās Kremlis izrādīja zināmu gatavību turpināt normalizèt attiecības ar Rietumiem un starptautiskā politika pārliecinoši virzījās uz "atslābuma politiku”, kas vēlāk kḷuva pazīstama ar apzīmējumu détente jeb detante.

"Brežñeva detante no agrākā atkušña [ietekmes uz starptautiskajām attiecībām] atšksīāas divos veidos. Pirmkārt, tā bija visaptverošāka un ar plašăkiem mērkiem. Divas lielvaras parakstija vairāk nekā divus dučus lūgumu, tai skaitā par bruņojuma ierobežošanu, krī̌̌u novēršanu un risināšanu, Austrumu-Rietumu tirdzniecìbu, Eiropas drošỉbu un pat cilvēktiesībām. Otrkārt, Brežneva detante bija balstita abu lielvaru militārā paritātē." 10

Kā norāda krievu vēsturnieks un literatūrkritikis Boriss Sokolovs (Boris Sokolov), 60. gadu otrajā pusē daudzi faktori objektīvi spieda Maskavu normalizēt attiecības ar Rietumiem. To noteica gan izpratne par to, ka Eiropā vairs nav iespējama tālāka padomju ekspansija, kas nenovestu pie pilna apmēra kodolkara, gan konflikts ar Kīnu, tāpat arī PSRS ekonomiskie apstākḷi, kur sadarbība ar Rietumiem l,autu noregulēt preču importu no Rietumeiropas un ASV. ${ }^{11}$ Britu politologs Maiks Boukers (Mike Bowker) savukārt atzīmē, ka Leonīds Brežṇevs (Leonid Brezhnev) "detanti redzēja kā lìdzekli PSRS kā lielvaras statusa formalizēšanai”, un norāda arī uz PSRS vēlmi nostiprināt savu lomu Austrumeiropā, vairs neorientējoties uz staļiniska stila vadību blokā, tomēr "rezervējot tiesības pielietot spēku, ja tas tiktu uzskatīts par nepieciešamu" (proti, realizēt t. s. "Brežñeva doktrīnu"). ${ }^{12}$

"Atslābuma" politikas un padomju ideoloǵijas kontekstā nozīmīgākā bija 1975. gada 1. augustā Eiropas drošības un sadarbības konferencē noslēgtā Helsinku vienošanās jeb Noslēguma akts (Helsinki Final Act of 1975), kas, britu vēsturnieka Tonija Džada (Tony Judt) vārdiem runājot, "iesainoja pastāvošo starptautisko kārtību dāvanas iesainojumā". ${ }^{13}$ Ar tās palīdzību PSRS ieguva iespēju realizēt tās seno vēlmi juridiski nostiprināt "status quo" stāvokli Eiropā, proti, pēckara politisko un ideologisko dalījumu. Arī ievērojamais amerikānu diplomāts Henrijs Kisindžers (Henry Kissinger) norādījis, ka "šis gigantiskais diplomātiskais process izauga no Maskavas dzil̄ās nedrošỉbas sajūtas un neapslāpējamās kāres pēc leğitimitātes". ${ }^{14}$

Padomju Savienībai neērtākais bija vienošanās "trešais grozs" (Basket 3), kas aplūkoja informācijas brīvas aprites un cilvēktiesību problēmas - to izstrādāja jau no 70. gadu sākuma, un uz tā iekḷaušanu Noslēguma aktā uzstāja Rietumi. ${ }^{15}$

\begin{abstract}
"Padomju Savienïba izrādīja mazu interesi par šo tēmu, bet beigu beigās pārtrauca sarunu apdraudēšanu. Mēgínājumi pārtraukt Rietumu raidstaciju raidǐšanu [uz PSRS] neizdevās. 1973. gada decembri "Voice of America", "Deutsche Welle" un BBC raiditāju slāpēšana tika pārtraukta."16
\end{abstract}

1974. gadā tika pārtrauktas 1956. gadā sāktās regulārās Igaunijas TV "kontrpropagandas" pārraides somu valodā, baidoties no apsūdzībām, ka PSRS raida citu valstu pilsoniem adresētas pārraides. ${ }^{17}$ Lai arī šāds solis acīmredzami norāda uz Padomju Savienības gatavību darīt visu, lai noslēgtu vienošanos, šādiem pasākumiem bija tikai 
taktisks raksturs - PSRS nebija gatava principiāli mainīt tās informācijas plūsmu kontroles politiku. ${ }^{18}$ Panākusi sev izdevīgus nosacījumus citās Helsinku vienošanās daḷās, komunistu režìma varas spice bija izbrīnīta par Rietumu konsekvenci, arī pēc tās noslēgšanas pieprasot sociālistiskajām valstīm ievērot "trešā groza" nosacījumus, proti, "samazināt barjeras informācijas plūsmām". ${ }^{19}$ Šādu izbrīnu, visticamāk, noteica kḷūdainā interpretācija, kas vadijja padomju politiḳus, sagatavojot un noslēdzot Helsinku vienošanos: padomju vadība, škiet, bija rēkinājusies, ka pēc "ietekmes sfēru" formalizēšanas Rietumi vairs nebūs ieinteresēti tās virzienā raidīt radioviḷnus, vai arī uzskatīja, ka vienošanās "pirmais grozs" (kas noteica valstu suverenitāti) ir svarīgāks par pārējiem. Otrais uzskats zināmā mērā bijis novērojams sarunu gaitā - padomju puse uzskatījusi, ka atzītā padomju suverenitāte neḷaus Rietumiem iejaukties tās iekšpolitikā, respektīvi, laus ignorēt "trešajā grozā" noteikto informācijas aprites brīvību un cilvēktiesību ievērošanu. ${ }^{20}$

Līdz ar PSRS nespēju ietekmēt Rietumu rīcību informācijas aprites jautājumā vairojās režīma vadības neapmierinātība ar propagandas darbu: sociologisko pētījumu dati jau no 70. gadu vidus liecināja, ka padomju iekšējam patēriņam paredzētā propaganda nesniedz vēlamos rezultātus. 1978. gada 27. novembrī Padomju Savienības Komunistiskās partijas (PSKP) Centrālās komitejas (CK) generālsekretārs L. Brežņevs runā PSKP CK plēnumā kritizēja partijas propagandas un informācijas daļas darbu, bet 1979. gada 6. maijā, kad starptautiskā politika bija nonākusi jauna saspīlējuma perioda sākumposmā, tika publicēts CK lēmuma teksts par turpmāko ideologisiskā darba veikšanu Padomju Savienībā. ${ }^{21}$ Lēmumā "Par tālāku ideologiskā un politiskās audzināšanas darba uzlabošanu" tika konstatēts, ka galvenais trūkums idejiski audzinošajā darbā ir “šì darba kvalitātes bieža neatbilstība pieaugušajam padomju cilvēka izglitibas un kultūras lìmenim, padomju cilvēku prasībām, nepietiekami vērtēta sociālekonomisko procesu un mūsdienu padomju sabiedrïbas dzìves dinamika. Ne vienmēr pienācīgā mērā ñemts verrā tas, ka ideologiskās cinnas raksturs starptautiskajā arēnā ir strauji saasinājies". ${ }^{22}$

Tāpat lēmumā norādīts, ka "presei, televizijai, radio, mutiskajai propagandai un aǵitācijai vēl lielākā pakāpē jāpalìdz padomju cilvēkam labi orientēties gan iekšējā dzìvē, gan starptautiskajos notikumos [...] jāattīsta uzbrūkošs [oriğ. nastupatel'nyj] propagandas un aǵitācijas raksturs". ${ }^{23}$ Zìmīgi, ka šajā uzskaitījumā nav iekḷauts kinematogrāfs. Visticamāk, šāda situācija apstiprina uzskatu, ka 70. gados padomju kino ideologiskā funkcija lielā mērā pārgāja televīzijas ziṇā. Kā vērtēja aukstā kara pētnieks, amerikānis Rodžers Kanets (Roger Kanet), "šajā situācijā [...] funkcionāri domāja, ka būtu atbalstāmi iniciēt "kontrpropagandas pasākumus", lai vājinātu [Helsinku] konferences un tās noslēguma vienošanās radìtos draudus". ${ }^{24}$

Realitātē ar šo lēmumu tika aizsākta pret Rietumiem vērsta propagandas kampaņa. Dažādos formātos un izpausmēs tā tika turpināta līdz pat Mihaila Gorbačova (Mikhail Gorbachev) nonākšanai PSKP CK ǵenerālsekretāra amatā 1985. gadā. Piel̦aujams, ka pastarpinātā veidā daḷa no šīs kampanas bija pētỉjumā aplūkotās Rīgas kinostudijas televīzijas mākslas filmas par Rietumu sabiedrību. Tomēr labvēlīgus apstākḷus šādu filmu tapšanai noteica ne vien režīma ideologiskā un politiskā attīstība, bet arī kultūras un mākslas procesu attīstības logika un to ietekmējošie faktori.

\section{Padomju kino kontroles mehānismi}

Atšķirībā no citām padomju kultūras nozarēm vai plašsaziṇas līdzekḷiem 
kinematogrāfijas gadījumā nav iespējams runāt par cenzūru kā par "dokumentos fiksēetu un skaidri redzamu kontroles struktūru". ${ }^{25}$ Iekšēji Rīgas kinostudijas radošo darbību mākslas filmu jautājumos pētāmajā periodā organizēja ar t. s. "koleǵiālo institūciju" starpniecību - tās bija Mākslas padome (no 1954. gada ${ }^{26}$ ) un Scenāriju redakcijas kolēǵija (no 1962. gada ${ }^{27}$ ). Taču kinematogrāfijas radošo procesu lielā mērā ietekmēja arī mākslinieku pašcenzūra un dažkārt - uzraudzība "no malas", t. i., ārpus kino jomas, ko kino zinātniece I. Pērkone, sekojot tās nosacītajam strukturālajam veidolam un darbības metodēm, precīzi apzīmējusi kā "izkaisīto cenzūru". ${ }^{28}$

Tematisko un estētisko uzraudzību pār kinomākslu pārsvarā nodrošināja kinematogrāfisti paši, un tas notika ar jau minēto institūciju starpniecību:

"Kolektiva apspriešana visos filmas tapšanas posmos daudz efektīvāk ierobežoja indivīda izteiksmes brīvību un novērsa dažādus zemtekstus, nekā to spēja oficiālie kontroles orgāni, kuriem bija jāisteno normatìvos noteikta uzraudziba pār tekstu vai attēlu; ar normatīiem bija sarežğitāk novērst netiešus, vien intuitīi sajūtamus "pārkāpumus". Kolektivā apspriešana, kā vēlāk atzina Latvijas PSR Valsts Kinematogrāfijas komitejas priekšsēdētājs Nikolajs Kārkliňš, bija izvirtusi sistēma, tā lāava izvairities no personiskās atbildỉbas, deva iespēju vainu vienmēr novelt $u z$ kādu citu." ${ }^{29}$

"Bez trīskārtējās pārbaudes neiztika ne scenārijs, ne filma. Shēma: redkolēǵijas atzinums - kinostudijas Mākslas padomes ieteikums - Goskino vai Centrālās televizzijas gala slēdziens no Maskavas - bija obligāts jebkuram ekrāna darbam." 30

Šĩs "trijādības" "smadzenes"31 bija Scenāriju redakcijas kolēgija (neformālā saziṇā arī redkolēǵija) - struktūra, kas "kḷuva par svarīgāko institūciju padomju kinomākslas saturisko un stilistisko dominanšu noteikšanā no 60. gadiem lìdz pat padomju perioda beigām". ${ }^{32}$ Tieši tā kḷuva par kinomākslas ideologísko centru, caur kuru Komunistiskā partija īstenoja savu vadošo lomu. ${ }^{33}$ "Stagnācijas gados ne cenzūra kā tāda, bet gan tieši redaktūra istenoja visiem redzamu oficiālo kontroli par mākslinieciskās domas virzību. "34 Kā skaidro I. Pērkone, uz Scenāriju redakcijas kolēóijas vadītāja (galvenā redaktora) "nozimïbu filmu ražošanas hierarhijā norāda arī amata atalgojums - lielākais kinostudijā. Piemēram, 70.-80. gados Rigas kinostudijas direktors sañēma 250 rubl̦ pamatalgu un 30 rublu piemaksu, bet galvenajam redaktoram pamatalga bija 300 rublil". ${ }^{35}$ RKS Scenāriju redakcijas kolēgiju pirmais vadīja Latvijas Komunistiskās partijas CK ieceltais Arvīds Grigulis (1962-1967), ${ }^{36}$ pēc viņa - Jāzeps Osmanis (1967-1972), Uldis Norietis (1973-1976), Osvalds Kublanovs (1976-1981), Leo Rage (1981-1982), Lija Brīdaka (1982-1987) un Tālivaldis Margēvičs (1987-1990). ${ }^{37}$

\section{Padomju aktierkino pievēršanās izklaidējošam saturam}

Kā norādījis krievu kino pētnieks Valērijs Golovskojs (Valerij Golovskoj), atkusnis "izmainija padomju kino tik radikāli, ka nekādas [vēlākās] 70. gadu salnas to [vairs] nespēja atgriezt atpakal pie Stalina laikiem. Talantigu režisoru, scenāristu, operatoru, aktieru parādī̌̌anās 60. gados, pievēršanās jaunām tēmām un žanriem palìdzēja piesaistit kinozālēm skatitājus un noteica to kino vadošo lomu, kāda kino bija 50.-60. gadu kultūrā". ${ }^{38}$ Tas apvienojumā ar alternatīvu trūkumu brīvā laika pavadīšanai un izklaidei (īpaši ārpus pilsētām) nodrošināja daudzskaitlīgus un pieaugošus kino apmeklētības rādītājus un iespēju visai viegli nodarboties ar iedzīvotāju indoktrināciju: 
“Apmeklētiba palielinājās lìdz pat 1968. gadam, sasniedzot 19 apmeklējumus gadā per capita [salīizinājumam: Rietumeiropā kinoteātru apmeklētība 60. gados bija 5-9 apmeklējumi gadā per capita ${ }^{39}$ ], bet pēc [1975. gada] sākās kritums - 16 apmeklējumi 1978. gadā, 14,6 - 80. gadu sākumā [...]"40

Pirmo auditorijas kritumu 60. gadu beigās iezīmēja šķietami pastarpināti procesi, piemēram, tādi kā 1967. gada maijā ieviestā piecu dienu darba nedēḷa, ${ }^{41}$ kas radīja brīvā laika daudzuma palielināšanos un pirmoreiz faktiski piẹ̦āva iedzīvotāju mobilitāti - uz karstām pēdām sāka attīstīties tūrisms un nostiprinājās mazdārziṇu kultūra. ${ }^{42}$ Vienlaikus strauji palielinājās televīzijas pieejamība - tieši šis process tika uzskatīts par vienu no būtiskākajiem kinoauditorijas samazinājuma iemesliem. ${ }^{43}$ Kino pētniece Marina Kosinova (Marina Kosinova) savukārt norādījusi, ka noteicošais cēlonis apmeklētāju skaita kritumā tomēr bija "garlaicïgais, vienveidiggais padomju filmu repertuārs". ${ }^{44}$

Iepriekš aprakstītā tendence radīja galveno 70. gadu padomju kinematogrāfijas iezīmi - visai krasu pavērsienu (t. i., pārorientāciju) uz žanru daudzveidību un izklaidējošu kino.

"PSRS Goskino administrācija, vairāku radošo darbinieku atbalstita, piedāvāja pievērst uzmanību komēdijām, melodrāmām, piedzìvojumu un zinātniskās fantastikas lentēm, un pat katastrofu un šausmu filmām. No 70. gadu vidus par šì virziena teorētiki kḷva [režisors un scenārists] Andrejs Mihalkovs-Končalovskis. Viņš piedāvāja reorganizēt padomju kinoindustriju kā ražošanas, tā sižetiski tematiskā zin̄ā, tuvinot to amerikānu modelim." ${ }^{45}$

Pret to iebilda "daudzi kinematogrāfisti un dala ideologiskāa aparāta", uzskatot, ka padomju kino "ir vērtigs ar savām tradicijām" un ka padomju kinoindustrijai "nav ne Holivudas ražošanas iespēju, ne profesionālisma". ${ }^{46}$ Joprojām visai izteikts bijis arī agrāko gadu uzskats, ka komerciāli panākumi ir filmas "bezdvēseliskuma apliecinājums" un "Rietumu slimïba". ${ }^{47} 70$. gadi un 80 . gadu sākums, kā norādījis V. Golovskojs, no organizatoriskā viedokḷa padomju kino veidotājiem "pagāja divu savstarpēji izslēdzošu kino attistibas koncepciju zimme":

"Varas iestādes nevarēja pat domās piel̦aut kinoklubu kustibas attistïbu, veicināt "elitāras" auditorijas veidošanos vai ațiaut kaut nedaudziem māksliniekiem veidot filmas izglitotai publikai. Bet, no otras puses, ideologískās važas nel̦āva arī "komersantiem" darboties ar pilnu jaudu. Cenzūras škēeres un strauji kūstošās finanses asi ierobežoja "masinieku" radošās un ražošanas ieceres. Atsevišksas veiksmes, kā filma "Maskava asarām netic", nenoteica tendenci, kamēr televizija turpināja strauji pārṇemt iedzīivotāju brīvo laiku."48

Centienus pārorientēt kinomākslu uz izklaidi noteica arī divi citi būtiski apsvērumi. Pirmkārt, ekonomiskie:

"Ik gadu tika pārdoti 4,2 miljardi bilsešu, kas pie vidējās biletes cenas - 35 kapeikām par bil̦ti - ienesa ne mazums ieñèmumu. Termins "komerciālais kino" no lamuvārda, kas tika attiecināts tikai uz buržuāzisko kino, pēkšñi kḷuva par pievilcìgu un respektablu jēdzienu. Par komerciālām filmām sāka saukt masās populārās filmas iepretī elitāriem darbiem [...]." 49

Otrkārt, pārorientēšanos stimulēja arī televīzijas formāta pieaugošā pieejamība un popularitāte, jo varas acīs "televizijas attistïba zināmā mērā atbrìvoja kino no tā tīri propagandiskās funkcijas un palielināja mazāk ideoloǵizētu, uz izklaidi un atpūtu vērstu 
filmu parādīšanās iespēju". ${ }^{50}$ Turklāt, kā uzsvēris V. Golovskojs, 1980. gadā iespēja skatīties centrālās programmas bija jau 89\% PSRS iedzīvotāju. ${ }^{51}$

I. Pērkone skaidro:

"[...] padomju sabiedrïbas attistibai no atkušn,na ieejot stagnācijas fāzē, vērtïbu sistēma lıoti izteikti mainijās. [...] vērtïbu maiñas brīdì ekrāna realitāte, kas tika piedāvāta kā apkārt esošo realitāti apsteidzoša, kā solijums, pēkšņi klıvva par paralēlu realitāti, kas, gluži kā visur pasaulē, projicēja auditorijas neïstenotos sapñus, vēlmes, kompleksus". 52

Lìdz 70. gadu vidum reti sastopamās kriminālfilmas ien̦ēma īpašu vietu 70.-80. gadu kino žanriskās daudzveidības ainā, jo "kḷuva par pateicīgāko ekrānu reālajai, nevis vēlamajai padomju dzìvei, [turklāt] tieši šis žanrs spēja piedāvāt visplašāko raksturu un psihologisko tipu galeriju". ${ }^{33}$ Padomju kinematogrāfijā kriminālfilmas nospiedošā vairākumā tika izpēlētas kā detektīvs. Kaut gan kriminālfilmas šajā periodā aktīvi ražoja visās PSRS kinostudijās, tieši Rīgas kinostudija bieži tika identificēta ar detektīviem (80. gados RKS izpelnījās pat neformālu studijas "detektivfiḷm"54 apzīmējumu).

Kriminālfilmu žanra īpašo lomu noteica arī fakts, ka tas bija ne vien specifisks formāts padomju realitātes atainošanā, bet arī praktiski vienīgais spēlfilmu žanrs, kurā bija iespējams atveidot sava laika Rietumu sabiedrību (visas piecas Rīgas kinostudijas filmas par dzīvi aiz dzelzs priekškara ir tāda vai citāda veida kriminālfilmas). I. Pērkone skaidro, ka mākslas teorijas kontekstā nozieguma tēmas aktīva pārnešana uz Rietumiem izrietēja no žanra sadursmes ar sociālistiskā reālisma "centieniem rādìt uz ekrāna vēlamo, nevis esošo. Noziegums vēlamïbā neiederējās". ${ }^{55}$ Vienlaikus "uzskatāmā kapitālistiskās sistēmas sasaiste ar noziedzību kontrpropagandas filmās nevis notušēja, bet vēl vairāk aktualizēja jautājumu par noziedzibas cēloniem sociālismā" ${ }^{56}$

Žanriskā daudzveidība tās konkrētajā veidolā bija visai precīzs padomju sabiedrības psihologiiskā stāvokḷa atspoguḷojums, jo tās vienojošā pazīme bija neapzinātais aicinājums skatītājiem, tāpat kā filmu autoriem, no padomju realitātes vienkārši "aiziet". To pašu apstiprināja dati par filmu apmeklētību: kā norāda I. Pērkone, tajos "visai skaidri redzams - jo mazāk kādai filmai saskares ar realitāti, jo mazāk tajā klajas ideolog̣ijas un didaktikas, jo tā populārāka". ${ }^{57}$ Apmeklējuma līderpozīcijās bija ārzemju filmas, tām sekoja padomju komēdijas un pseidovēsturiskas piedzīvojumu filmas. ${ }^{58}$ Pēdējais žanrs 70. gados bija īpaši izplatīts arī Latvijā: tapa filmas "Vella kalpi" (1970) un "Vella kalpi Vella dzirnavās" (1972), "Melnā vēža spīlēs" (1975), "Robina Huda bultas" (1975) un "Zobena ēnā" (1976). Šo filmu popularitātes fenomens ir uzskatāms apliecinājums garīgajai krīzei, kādu pārdzìvoja padomju sabiedrība pēc atkušn,a perioda - "auditorija izvēlas eskeipismu, aiziešanu, atteikšanos". ${ }^{59}$ Līdzīgi procesi bija vērojami arī attieksmē pret filmu varoņiem - I. Pērkone spriež, ka padomju auditorija "bija nogurusi no sociālistiskā reālisma melni baltajiem, škiru cīnā balstitajiem varonsstāstiem un īpaši neinteresējās arī par eksistenciālu dilemmu mocìtajiem, modernisma inspirētajiem reflektējošajiem varoṇiem, kādi, par spīti visam, laiku pa laikam izlauzās uz padomju ekrāniem, piemēram, Andreja Tarkovska filmās". ${ }^{60}$ Šì problēma mazinājās, kad kinematogrāfa tematiskās transformēšanās rezultātā radās jauna tipa varoṇi un personāži, piemēram, komēdijas žanrā agrāko gadu "mazais smieklìgais cilvēks [...] deva vietu vidusmēra cilvēkam". ${ }^{61}$

70. un 80. gados būtiska padomju kinematogrāfijas iezīme bija arī literāro darbu ekranizēšana. Kino pētniece Jūlija Homjakova (Julija Homjakova) konstatējusi, ka 17 gadu laikā (t. i., no 1968. līdz 
1985. gadam) literārie darbi ekranizēti aptuveni 300 reižu. Viṇa norāda, ka "ne pirms, ne pēc ši perioda nevienā pasaules kinematogrāfijā (tai skaitā padomju) autori nevērsās pie nopietniem literārajiem pirmavotiem tik bieži”. ${ }^{62}$ Dažādu veidu ekranizāciju pārpilnība iezīmējusi pēcatkušņa kinematogrāfā "pasvītrotu pietāti pret intelektuālām sākotnēm mākslā". ${ }^{63}$ Lielo literāro darbu ekranizāciju skaitu noteica gan sabiedrība, kurā lasīšanai bija lıti nozīmīga loma, gan situācija, ka klasika bija daudzkārt vieglāk izlaižama cauri sazarotajai kontroles sistēmai nekā jebkurš cits literārs darbs.

Skatītāju nepatika izpaudās ne vien pret apnikušajiem padomju filmu varoñiem, bet arī pret darbības vidi. Kā uzskata J. Homjakova, "svarīgs iemesls, lai pievērstos literatūrai, bija tas, ka mūsu filmas salìdzinājumā ar ārzemju [filmām] zaudēja skatāmïbas zin̄ā. Holivudas un Eiropas, indiešu un arābu filmas palìdzēja izpildìt plānu arī tāpēc, ka padomju skatitājam bija neizturami apnicis uz ekrāna redzēt cehu, partijas komiteju, virtuvi, ciema padomi, strādnieku ciematus, kūpošus dūmeñus". ${ }^{64}$ Ekranizāciju skaita pieaugumu veicināja arī sociālistiskā reālisma kā mākslinieciskās metodes krīze:

\begin{abstract}
"Sabiedrībā pakāpeniski dzisa ticība "jaunās morāles" uzvarai [...] savukārt izveidot uz ekrāna situāciju, kurā [varētu] pilnvērtīgi atainot cilvēciskās kaislïbas un [vienlaikus] izbēgt no nopietnām problēmām ar cenzūru, kḷuva aizvien grūtāk. Sociālistiskā reālisma nosacijumi prasija, lai uz ekrāna katrs negativiais personāžs būtu kaut kādā veidā "lidzsvarots" ar atbilstošu pozitivo varoni. No šejienes arī visi daudzskaitlìgie gudro partkoma biedru vai Lielā Tēvijas kara veterānu tēli, kuri kā "Deus ex machina" iejaucās padomju kino varoṇu konfliktos."65
\end{abstract}

Šis apstāklis noteica negatīvo varoṇu vai vismaz negatīvu iezīmju īpašu koncentrāciju filmās par dzīvi Rietumos, lai gan arī to specifika paredzēja galvenos varoņus bieži iztēlot par savu dzives apstākḷu (proti, kapitālisma) upuriem.

Arī padomju mākslas filmas par Rietumiem tika veidotas kā literāro pirmavotu ekranizācijas. Kā norāda J. Homjakova, aprakstītā padomju filmu (ne)skatāmības problēma mudināja režisorus bēgt no vienveidības, "keroties pie katras iespējas Rīgu pārgèerbt par Londonu, L,eningradu - par Pēterburgu, aktierus - mundieros un krinolinos, nomainit "biedrs" un "pilsonite" uz "sers" un "madam"', ${ }^{66}$ Tādu ārzemju un padomju klasikas darbu ekranizēšana, kuru darbība notiek laikos, kad "vēl nebija ne partijas biroja, ne arodbiedrïbu komitejas, [...] l़āva "likumības robežās" atkāpties no sagrabējušā sociālistiskā reālisma dogmām". ${ }^{67}$ Tomēr arī šis filmu “žanrs" uzlika "pienākumus", kuri būtībā attiecās uz jebkuras padomju spēlfilmas veidošanu:

"Bija kategoriski aizliegts rādìt cilvēka biologisko dabu atrauti no sociālās. [...] Tika uzskatits, ka pat kapitālistiskajā sabiedrībā, kuru kritizēt varēja un vajadzēja, cilvēks nevar būt "vienkārši slikts"; šāds uzstādījums esot izplatits tikai buržuāziskajā mākslā tieši tāpēc, lai novērstu uzmanïbu no sociālajām problèmām. Tāpēc arī ekranizācijās, tāpat kā citās padomju gadu filmās, nekad nav tādu personāžu kā maniaki (un vispār garīgi slimie) vai arī kādu kaislïbu apsēstu cilvēku."68

J. Homjakova uzskata, ka visas šĩs filmas apvieno vēl viena būtiska iezīme, ko "pietiekami slimìi pārdzīvoja tā laika kinematogrāfisti", proti, nespēja pilnvērtīgi atveidot uz ekrāna "ārzemes":

“[Vis]grūtāk bija atrisināt problēmu ar aktieru pārveidošanos varonos, kuri tiem ir nepazistami tēla detaļu dinamiskā un mìmiskā konturējuma līmeni. Mūsu režisori un aktieri tik reti brauca uz kapitālistiskām valstīm, ka ne par kādām materiālās vides un tās 
vai citas sociālās grupas uzvedības standartu zināšanām nevarēja būt ne runas. [...] Tomēr ar laiku - pēc aizrobežu filmu masu uzplūda un palielinoties iespējām izbraukt uz ārzemèm - kļuva ìpaši pamanāma mūsu "filmu par ārzemēm" darbïbas vides neatbilstiba tam, kā tās pašas "ārzemes" reāli izskatās tuvumā. ${ }^{\prime 69}$

\section{Rīgas kinostudijas spēlfilmas par Rietumu sabiedrību}

No 1964. gada, kad ar pilnu jaudu darbu sāka Rīgas kinostudijas jaunā ēka (Rīgā, Šmerḷa ielā 3), sākās Latvijas kino "industriālais posms"70 - uzṇemto mākslas filmu jeb aktierfilmu skaits pieauga no 2-3 filmām ik gadu 60. gadu sākumā līdz 6-7 filmām gadā 70. gadu sākumā. ${ }^{71}$ Kā norāda I. Pērkone, šis jaunais darbības posms saistās arī ar studijas direktoru mainu: vispirms 1964. gadā Pāvelu Jankovski nomainīja Frīdens Koroḷkēvičs, bet 1968. gadā par "negaiditu brīvdomību" F. Koroḷēviču nomainīja Heinrihs Lepeško. ${ }^{72}$ Tieši pēdējā vadības laiks ir "Latvijas kino industrijas stabilākais un ražĭgākais posms": "Šajā laikā Rìgas kinostudijā par galveno tika uzskatita rentabilitāte, protams, n,emot vērā visus centralizètās plānveida ekonomikas uzspiestos kroplojumus."73 Studijas darba "industrializēšanos" veicināja arī tas, ka H. Lepeško drīz pēc stāšanās amatā panāca RKS kategorijas jeb apmaksas grupas paaugstināšanu: tika pien,emts lēmums no 1970. gada 1. aprīla RKS un tās darbiniekus ieskaitìt II apmaksas grupā, tas praksē nozīmēja, ka Rīgas studija "bija tikai kategoriju zemāk nekā PSRS lielās studijas "Mosfilm”, "L̦enfil,m” u. c.”. Apmaksas grupas paaugstinājums nozīmēja gan lielāku amata vietu skaitu, gan lielākas algas - bet arī nepieciešamību regulāri nodrošināt lielāku skaitu filmu. ${ }^{74}$

Filmas, kuras 70. gados Rīgas kinostudijā ražoja pēc Centrālās televīzijas pasūtījuma, bija neērts kompromiss starp CT un republikas "nacionālās" kinomākslas interesēm. Izñēmums nebija par 70. un 80. gadu RKS "standartpreci"75 sauktie, tostarp arī CT vajadzībām bieži uzņemtie detektīvi (1. att.) piecas televĩzijas mākslas filmas, kas balstītas uz ārzemju (britu, zviedru, amerikāṇu un austrumvācu) literārajiem pirmavotiem un ietvēra nozieguma tēmu.

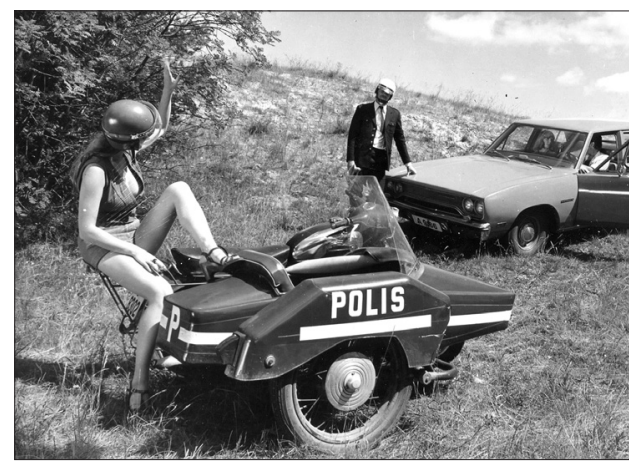

1. att. Filmas "Nepabeigtās vakariṇas" (režisors Jānis Streičs) epizode. 1979.

Avots: Rīgas Kino muzejs, RKM 14240. Foto: Guntis Grunte.

Fig. 1. A scene from the film Nepabeigtās vakariņas (director Jānis Streičs). 1979.

Source: Riga Film Museum Collection, RKM 14240. Photographer Guntis Grunte.

Pirmā no tām bija 1976. gadā uzṇemtā divsēriju filma "Nāve zem buras" (rež. Ada Neretniece, scen. aut. Viktors Lorencs) Čārlza Persija Snova (Charles Percy Snow) romāna "Nāve zem buras" (Death Under Sail, 1932) ekranizācija, tapusi pēc V. Lorenca ierosinājuma. 1979. gadā pēc CT pasūtījuma tika uzṇemta divsēriju filma "Nepabeigtās vakariņas" (rež. Jānis Streičs, scen. aut. Alvis Lapin̄š) - Pēra Valē (Per Wahlöö) un Maijas Šēvales (Maj Sjöwall) detektīvromāna "Policija, policija, kartupel̦u biezputra!" (Polis, polis, potatismos!, 1970) ekranizācija. 1983. gadā pēc režisora Aloiza Brenča ierosinājuma tapa trīssēriju filma "Mirāža" (rež. A. Brenčs, scen. aut. A. Lapiņš) - uzņemta 
pēc Džeimsa Hedlija Čeiza (James Hadley Chase) romāna "Visa pasaule kabatā" (The World in My Pocket, 1959) motīviem. Šī filma ir gan vislabāk pazīstamais, gan par veiksmīgāko uzskatītais RKS "kontrpropagandas" darbs. 1984. gadā tika uzñemta filma "Pēdējā vizīte" (rež. A. Neretniece, scen. aut. Irina Čerevičnika) - darbs pēc Alberta Karra (Albert H. Zolotkoff Carr) garstāsta "Slepkavība Vašingtonā" (The Washington Party Murder, 1964) motīviem. Filmu grupu noslēdza 1986. gadā uzṇemtā divsēriju filma "Pēdējā reportāža" (rež. Dzidra Ritenberga, scen. aut. Jurijs Kalıščuks) - tapusi pēc Gerta Prokopa (Gert Prokop) romāna "Reportiera nāve" (Der Tod des Reporters, 1973) motīviem.

Šo filmu scenāriju darbība pilnībā norisinājās "kapitālistiskajos Rietumos", tādēl līdzās skatītāju izklaidēšanai l, loti būtisks šo filmu uzdevums bija arī "kontrpropagandas" funkcijas realizēšana. ${ }^{76}$ Lai gan bieži nosacīti sauktas tieši par detektīviem, žanriski šīs filmas ietver sevī dažādus noziedzības aspektus, ne tikai nozieguma izmeklēšanu un atklāšanu. Šajā kontekstā īpaša ir filma "Mirāža", kurā galvenie varoṇi ir noziedznieki un centrā ir nozieguma plānošana un īstenošana, nevis tā atklāšana. Šo filmu atškirīgā ievirze ir îpaši jūtama, pretnostatot tās "klasiskām" padomju detektīvfilmām ar sižeta darbību PSRS iekšienē, kur milicija un prokuratūra vienmēr "uzvar". ${ }^{77}$

Kamēr ir zināmi vien daži līdzīgu "kontrpropagandas" filmu piemēri citās PSRS kinostudijās (divas Mosfilı studijā, viena Tallinnfilm, viena Moldova-film studijā u. tml.), RKS nepilnu desmit gadu laikā tika uznemtas pavisam piecas šādas ievirzes televīzijas mākslas filmas. Visticamāk, to noteica RKS sasniegumi televīzijas mākslas filmu žanrā kopumā - vissavienības mērogā grandiozus panākumus guva J. Streiča televīzijas mākslas filma "Teātris" (1978) un A. Brenča daudzsēriju televīzijas mākslas filma "Ilgais ceḷš kāpās" (1981) -, kā arī studijas augstā ražošanas kategorija un direktora $\mathrm{H}$. Lepeško izteiktā interese par studijas prestiža uzturēšanu. Būtiska loma varēja būt arī faktam, ka RKS ražotā produkcija ar 17,5 miljoniem skatītāju bija otra visvairāk skatītā visā PSRS (1976) un tikai nedaudz atpalika no "studiju studijas" Mosfiḷm, kuras rādītājs bija 17,7 miljoni. ${ }^{78}$ Iepriekš izklāstîtie iemesli veidoja apstākḷus, lai CT vai vietējo kinematogrāfistu individuālas iniciatīvas veidā RKS varētu tapt uz ārzemju autoru literāriem darbiem balstītas filmas par dzīvi "kapitālistiskajos Rietumos".

"Kontrpropagandas" integrēšana pētāmo filmu saturā tika īstenota ar zināmām grūtībām, jo filmu tapšanā tomēr dominēja pret jebkuru filmu vienādi attiecinātie studijas mākslinieciski estētiskie kritēriji. Ideologiiskās funkcijas patstāvīgā īstenošanā RKS spējas bija zemas; studiju vairāk interesēja tās kā mākslas organizācijas prestiža - t. s. "studijas markas" - uzturēšana, par to liecina strīdi par aktierspēles izteiksmību vai sižeta attīstības loǵiku. Šādas pieejas nostiprināšanos tikai sekmēja fakts, ka RKS darbinieku viedoklim filmu ideologiskās ievirzes kontekstā patiesībā nebija izšķirošas nozīmes: kā filmu pasūtītājs CT literārajos scenārijos vienmēr vēlējās "saasināt sociālo konfliktu", "padziḷināt tēlu sociālos raksturojumus" un "pastiprināt kontrpropagandisko ievirzi" - neatkarīgi no tā, vai RKS iekšienē pret scenāriju bija iebildumi, vai tas tika uztverts kā gatavs darbs, kurā nav nekā "labojama". Turklāt dažkārt CT sev vēlamu risinājumu uzspieda konkrētu norādījumu un montāžas labojumu veidā darba pēdējās stadijās.

RKS arī pat nemēgināja pārbaudìt savstarpējās sadarbības "elastību”. Lai gan pēc savas subjektīvās izpratnes, tomēr formāli šo filmu tapšanā vārds vārdā tika izpildīti praktiski visi CT slēdzienos paustie norādījumi, neizpildot tos vienīgi tādos gadījumos, kad tas vairs fiziski nav iespējams. Divos gadījumos, kad konkrēti CT ieteikumi 
netika izpildīti izṇēmuma kārtā (tos bija iespējams ievērot), nesekoja pasūtītāja kritiska reakcija. Tas norāda, ka, uzskatot sevi par darba izpildītāju, nevis pilnvērtīgu tā autoru, RKS neizmantoja visas iespējas ietekmēt pētāmo filmu saturu. Ir iespējams izteikt visai ticamu pieņēmumu, ka priekšstatu un zināšanu trūkuma dēḷ RKS patiesībā nebija intereses strīdēties par šādu filmu saturu - "centra" zināšanas, visticamāk, bija tikpat ierobežotas, taču to dominanci noteica pasūtītāja un hierarhijā augstāk stāvošā privilegètais stāvoklis. Tā vietā RKS visai pamatoti varēja būt ieinteresēta "cīnīties" par tādu filmu "patiesīgumu", kas skāra latviešus un Latvijas vēstures interpretācijas jautājumus. Noprotams, ka CT savukārt pieḷāva zināmas atkāpes no savu slēdzienu realizācijas, jo apzinājās, ka līdz pat filmas iznākšanai uz ekrāniem var ietekmēt un novērst sev nepatīkamas detaļas ar slēdzienu, pavēḷu, montāžas labojumu plānu un filmas ieskaņošanas palīdzību.

N̦emot vērā, ka aktieru pielāgošana specifiskām pasūtītāja vēlmēm filmēšanas laikā bija ārkārtīgi ierobežota, to "atbilstību" tēliem, n,emot vērā arī filmu specifisko ievirzi, īpaši rūpīgi vērtēja kā RKS, tā Centrālajā televīzijā. Šajā kontekstā spilgti ilustratīvs ir RKS direktora H. Lepeško izteikums 1985. gada 20. novembrī, Mākslas padomes sēdē vērtējot filmas "Pēdējā reportāža" aktieru kinomēǵginājumus: "Lai die's jums stāv klāt CT padomē, kur apstiprinās proves!"79 Daiḷrunīgs ir arī filmas redaktora Vladlena Dozorceva (Vladlen Dozorcev) komentārs tās pašas filmas skatē 1986. gada 1. augustā: "Ir palikušas dažas neizpildìtas CT prasības. Tās arī nav izpildāmas, jo nāca pārāk vēlu. Viñi grib, piemēram, lai [komunistu] avizes "Der Arbeiter" redaktors būtu simpātisks." ${ }^{80}$

Konkrēto filmu veidošanā neizbēgams bija padomju kinematogrāfijas nerakstītais likums neskatīt cilvēka biologisko dabu atrauti no sociālās. Tas noteica to, ka visas piecas RKS filmas par Rietumu sabiedrību neatkarīgi no literārā pirmavota ievirzes tika izveidotas pēc vienas shēmas: cilvēku līdz noziedzīgai rīcībai noved dzīve buržuāziskajā sabiedrībā; galvenie varoṇi tādā vai citādā veidā ir "sistēmas upuri". Šo shēmu savos slēdzienos uzstājīgi un nepārprotami pieprasīja filmu pasūtītājs - Centrālā televīzija:

"Svarīgi vēl vairāk pastiprināt scenārija sociālo saasinātību, padzilināt motīvu, ka tieši buržuāziskā sabiedrība ar tās iedzīvošanās kultu, kad nauda ir cilvēka dzìves augstākā jēga, padarïjusi varoṇus par noziedzniekiem un sagatavojusi viņu bojāeju."

Sākotnēji šî formula vēl nebija pašsaprotama - piemēram, apspriežot filmas "Nāve zem buras" režisora scenāriju, mūzikas redaktors Nikolajs Zolotonoss (Nikolaj Zolotonos) kolēgiem uzdeva jautājumu par ekranizējamā romāna "socializēšanas" leg̣itimitāti: "Ar kādām acīm mēs skatāmies uz šo sabiedrïbu - ar Snova vai savām?"82 Pēc dažiem gadiem, vērtējot filmas "Nepabeigtās vakariņas” scenāriju, redaktors T. Margēvičs sacīja: "Žēel, ka slepkava izrādās nabags, nevis kāds no bagātniekiem. Bet tur nekā nevar darìt, jo tā ir romānā." "83 Vina viedoklim publiski pievienojās arī redaktore Austra Zīle. Taču laika gaitā studijas darbinieki šo log̣iku spēja apgūt bez īpašas piepūles: RKS direktors H. Lepeško 1982. gada 7. decembrī, skatot pirmo filmas "Mirāža" uzñemto materiālu, aicināja kolēgus piedomāt, "lai filma vairāk tiktu veidota ar kontrpropagandisku ievirzi. Tieši tās dēl CT ielaida šo filmu ražošanā. Jāparāda pretrunas dotajā sabiedrībā, kas šos cilvēkus noveda līdz tādai rìcibai" ${ }^{84}$ Režisore Dz. Ritenberga tajā pašā reizē apliecināja: "Katrā cilvēkā jūtu traǵēediju, jūtu, kas licis dzìties pēc naudas." ${ }^{85}$ Bet 1983. gada 7. jūnijā, vērtējot filmas "Pēdējā vizīte" scenāriju, redaktors V. Dozorcevs shēmas būtību konkrētās filmas kontekstā 
rezumēja jau pavisam kodolīgi: "Slepkavība ir sistèmas, nevis gimenes lieta."

Tajā pašā laikā katra filma tika veidota un vērtēta kā individuāls mākslas fakts un atkarībā no scenārista un režisora talanta filmas fabula varēja iegūt spēcīgu autoru individuālā rokraksta skanējumu, kā gadījumā ar J. Streiča filmu "Nepabeigtās vakariņas" (2. att.). Taču no pasūtītāja skatpunkta šāds iznākums tika uzskatīts par blakni, jo sarežǵīja "kontrpropagandas" "ziņojumu" nolasāmību, tādēḷ J. Streiča filma bija vienīgā, kura Maskavā tika novērtēta zemāk nekā Rīgā. ${ }^{87}$

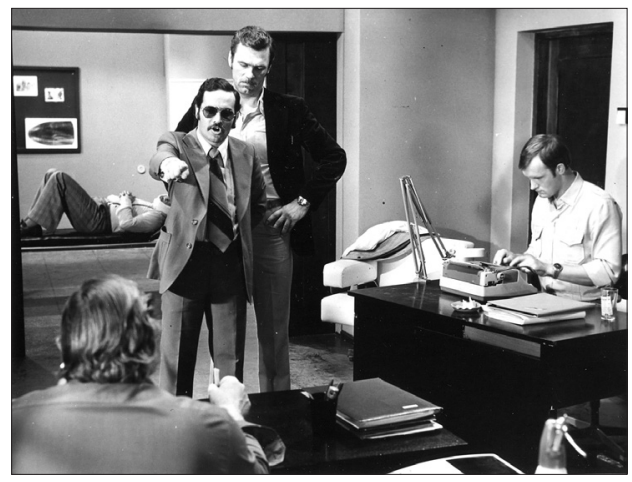

2. att. Filmas "Nepabeigtās vakariṇas" (režisors Jānis Streičs) epizode. 1979.

Avots: Rīgas Kino muzejs, RKM 14492. Foto: Guntis Grunte.

Fig. 2. A scene from the film Nepabeigtãs vakariṇas (director Jānis Streičs). 1979.

Source: Riga Film Museum Collection, RKM 14492. Photographer Guntis Grunte.

To pašu apliecina arī balansēšana uz žanra un ideologisiskās funkcijas robežas CT skatījumā konkrētās filmas nekādā gadījumā nedrīkstēja būt vienīgi detektīvs bez "kontrpropagandiskas" ievirzes, taču vienlaikus "kontrpropagandas" funkcijas integrēšana nedrīkstēja traucēt vispārējai sižeta intrigai un detektīvlīnijas dinamiskai attīstībai. Tas lielā mērā sakrita arī ar RKS darbinieku viedokli - filma
"Mirāža" (3. att.) viṇu skatījumā bija labākais "kontrpropagandas" darbs tieši tāpēc, ka ideologiiskā funkcija ar detektīvlīniju tajā tika sasaistīta "organiski" un "iepotēta bez didaktikas" - filma bija aizraujoša un vienlaikus realizēja ideoloǵisko funkciju.

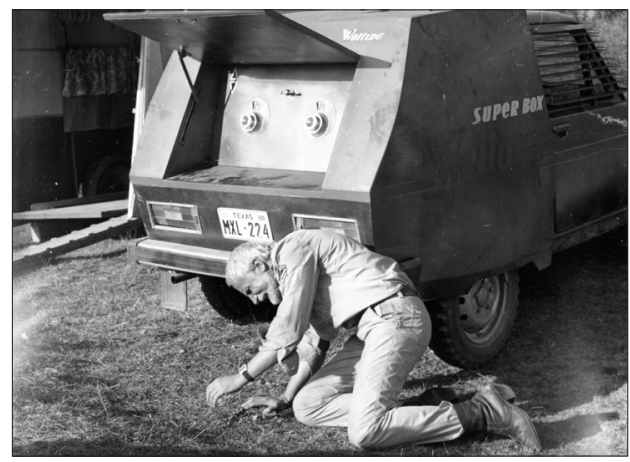

3. att. Filmas “Mirāža” (režisors Aloizs Brenčs) epizode. Vjetnamas kara veterāna Bleika lomā aktieris Ints Burāns. 1983.

Avots: Rīgas Kino muzejs, RKM 162. Foto: Uldis Ofkants.

Fig. 3. A scene from the film Mirăža (director Aloizs Brenčs). Vietnam War veteran Blake played by Ints Burāns. 1983.

Source: Riga Film Museum Collection, RKM 162. Photographer Uldis Ofkants.

Kā sava veida pretmetu iespējams minēt situāciju filmas "Nāve zem buras" veidošanas laikā, kad kā "pārāk tieša" scenārija tika izmesta kāda varoṇa replika: "Ar prātu es daudz ko saprotu. Es pat piekritu, ka sociālisms ir labāks par kapitālismu." 89

Taču kopumā neskaidrie kritēriji skatītājus "audzinošās" "kontrpropagandas" funkcijas integrēšanā un izpratnes trūkums par to, kāds optimālais rezultāts iegūstams no šāda veida filmām, noteica to būtiskākos trūkumus. Visas pētāmās filmas objektīvu iemeslu dēḷ raksturo nespēja ticami atveidot Rietumu darbības vidi - pasūtītāja dotais uzdevums nekad neparedzēja iespēju filmēt ārzemēs, un tas laika gaitā grāva filmu ticamību auditorijas acīs. ${ }^{90}$ 
Galvenais filmu trūkums pašu kinematogrāfistu skatījumā bija aktieru nespēja iejusties Rietumu sabiedrības tēlos: reālu priekšstatu neesamības dēl aktierspēle bieži bija samākslota un intuitīva, tā nesakrita ar tikpat intuitīviem un subjektīviem vērtējošo institūciju spriedumiem par to, kādiem jābūt Rietumu cilvēkiem. Tieši aktierprovju un uzṇemtā materiāla vērtēšanā visspilgtāk izpaudās filmu veidošanā un vērtēšanā iesaistīto RKS darbinieku privātie un kvaziideoloǵiskie priekšstati par Rietumiem un Rietumu sabiedrību:

“[Brenčs] ir redzējis tādus cilvēkus Liverpūlē... Šeit visiem ir jāslēpj savi skatieni..." (Režisors Ol,gerts Dunkers 1976. gada 12. martā Mākslas padomes sēdē, vērtējot filmas "Nāve zem buras" aktieru kinomēǵinājumus.)

"Bet kur lai viņš uzzina, kā jāuzvedas bagātniekam? Vina spēlei nebūs tāda smalkuma un nianšu, ko gribējās redzēt, tāpēc režisorei jāpasvītro vina intelektuālā aprobežotỉba, nevis aristokrātiskums." ${ }^{22}$ (Redaktors Arnolds Serdants 1976. gada 28. maijā Mākslas padomes sēdē, vērtējot filmas "Nāve zem buras" uzņemto materiālu.)

"Viņš ir bagāts. Nav beidzis pat Oksfordas universitāti. Girts Jakovl̦evs gan to ir beidzis, kas ir redzams arī vina sejā." ${ }^{93}$ (Scenārists V. Lorencs 1976. gada 28. maijā Mākslas padomes sēdē, vērtējot filmas "Nāve zem buras" uzṇemto materiālu.)

“Angli nerunā ar krievu valodas gājieniem. Anglu valodā nav kategorisku atbilžu. Viṇi lieto "man šksiet”, "man liekas" un tamlìzigi." 94 (Studijas direktors H. Lepeško 1976. gada 28. maijā Mākslas padomes sēdē, vērtējot filmas "Nāve zem buras" uzṇemto materiālu.)

"Adomaitis un Burāns spēlē tajā stilā, kā visi padomju aktieri filmās par ārzemēm
[...] ši tišā nevērība ir bistams stils, tā var aizvest aktierus sāñus." ${ }^{95}$ (Režisors Pēteris Krilovs 1982. gada 17. jūnijā Mākslas padomes sēdē, vērtējot filmas "Mirāža" aktieru kinomēgeinājumus.)

"Par nacionālo tipu nav ko runāt, Amerikā ir visi eiropiešu tipi. Amerikāṇi atšksiras ar pārākuma sajūtu uzskatos un uzvedībā. Tas rada brìvu kustibu, ko mēs aktieriem liekam atdarināt un no kā nekas neiznāk." ${ }^{96}$ (Studijas direktors H. Lepeško 1982. gada 17. jūnijā Mākslas padomes sēdē, vērtējot filmas "Mirāža" aktieru kinomēǵinājumus.)

"Kapitālistisko valstu cilvēki tomēr loti atšķiras no sociālistisko valstu cilvēkiem pēc izturēšanās un tā tālāk. "Mirāžā" to neizdevās panākt. Nezinu, vai Vasiljevs spēèe labi vai slikti, taču par senatoru tādu cilvēku neievēlētu. Vinšs nav arī amerikānis - pārāk tumšādains. Skorohodova neatgādina meiteni no augstākās sabiedrïbas. [...] Grupa var strādāt ar izvēlētajiem aktieriem, taču jāpatur prātā, ka videi un cilvēkiem jābūt organiskiem." ${ }^{97}$ (Studijas direktors H. Lepeško 1984. gada 29. martā Mākslas padomes sēdē, vērtējot filmas "Pēdējā vizīte" aktieru kinomēǵinājumus.)

"Skorohodovas kandidatūra ir izteikti krieviska, bet Amerikā taču dzìvo dažādi cilvēki." ${ }^{98}$ (Režisore Dz. Ritenberga 1984. gada 29. martā Mākslas padomes sēdē, vērtējot filmas "Pēdējā vizìte" aktieru kinomēgóninājumus.)

"Vasiljevs vēl neizskatās pēc tipiska amerikāṇa. Iekšējai pasaulei jāatbilst ārējam izskatam."99 (Uldis Šteins 1984. gada 29. martā Mākslas padomes sēdē, vērtējot filmas "Pēdējā vizīte" aktieru kinomēgoinājumus.)

"Visi pārējie aktieri sāk spēlēt ārzemniekus un ārzemju dzivi. Lìdz ar to viss izskatās nereāli. Režisorei vajag aktieriem ieskaidrot, 
lai viñi aizmirst, $k a$ ir ärzemnieki." 100 (Redaktore I. Čerevičņika 1985. gada 20. novembrī Mākslas padomes sēdē, vērtējot filmas "Pēdējā reportāža" aktieru kinomēǵinājumus.)

Filmu ideologiskās funkcijas integrēšanas kontekstā niecīga loma tika atvēlēta mūzikai, dekorācijām un kostīmiem - noteicošā loma bija varoniiem, to "sociālajam raksturojumam”, tos atveidojošiem aktieriem un scenārija tekstam.

Laika gaitā nostiprinājās vēl daži svarīgākie šo filmu veidošanas principi - tuvojoties 80. gadu vidum, RKS darbinieki atklāti runāja par darba veidošanu pēc pirmavota motīviem, nevis "tiešu" ekranizēšanu, ja juta nepieciešamību brīvāk rīkoties ar darba kontrpropagandas ievirzi. Tādēḷ likumsakarīgi, ka asāk izteikta ideoloǵiskā funkcija jūtama filmās, kuras balstītas tikai uz literārā pirmavota motīviem. Tā 1983. gada 7. jūnijā, vērtējot filmas "Pēdējā vizīte" (4. att.) scenāriju, redaktors Antons Broks ieteica scenārija autorei I. Čerevičnikai rīkoties ar darba materiālu brīvāk: "Var taču veidot filmu pēc motiviem. Vajadzìga spēcīgāka sociālā bāze."101

Būtiska loma filmu veidošanas procesā bija noteiktām vērtēšanas praksēm kā tādām. Tā, piemēram, lai arī uz "kontrpropagandas" filmām attiecās televīzijas mākslas filmu standarta vērtēšanas kārtība, izstrādājās noteikts profesionālās saziņas kods. 70. gados tapušo filmu ("Nāve zem buras" un "Nepabeigtās vakariņas") apspriešanu iezīmē plašs tādu jēdzienu lietojums, kuri būtībā apzīmē "kontrpropagandas" funkcijas veidošanu, taču nenosauc to vārdā: "sociālais skanējums", "personāžu sociālais raksturojums", "sociālās raksturiezīmes", "sociālais satvars", "sociālais kontrasts", "sociālie momenti", "sociālie motīvi" u. tml. 80. gados šādu eifēmismu lietojuma biežums samazinās, tos aizstāj jēdzieni "kontrpropaganda", "kontrpropagandisks", dažos gadījumos arī "propaganda", kas liecina par ideologiskās gaisotnes saasināšanos, starptautiskās politikas atslābumam pārejot jaunā saspīlējumā, kā arī par iepriekš aprakstītā PSKP CK 1979. gada lēmuma "Par tālāku ideologískā un politiskās audzināšanas darba uzlabošanu" ietekmi uz kultūras procesiem.

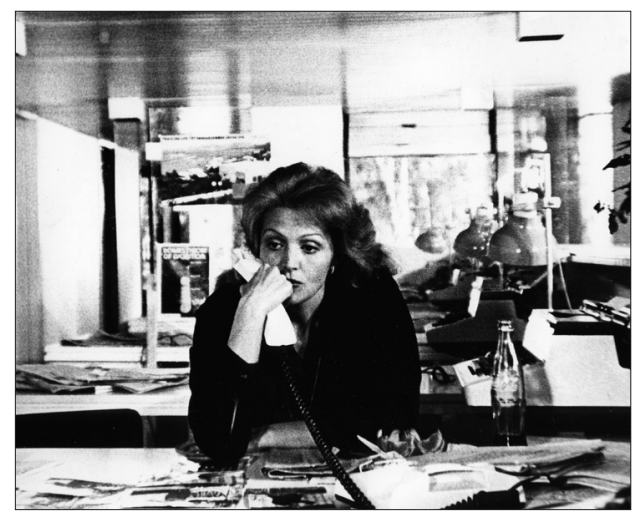

4. att. Filmas “Pēdējā vizīte” (režisore Ada Neretniece) epizode. Galvenās varones žurnālistes Sāras Bertones lomā - aktrise Alla Baltere. 1984.

Avots: Rīgas Kino muzejs, RKM 172.

Fig. 4. A scene from the film Pēdējā vizìte (director Ada Neretniece). The main character, journalist Sarah Burton, played by Alla Baltere. 1984.

Source: Riga Film Museum Collection, RKM 172.

Būtiska loma filmu tapšanas procesā bija starptautiskajai politikai - kā vietējā, tā Maskavas redaktūra uzskatīja par nepieciešamu pēc iespējas izvairīties no oficiāliem Rietumvalstu simboliem un nosaukumiem. Piemēram, 1979. gada 12. aprīlī, apspriežot filmas "Nepabeigtās vakariņas" - zviedru romāna ekranizācijas - režisora scenāriju, RKS redaktore I. Čerevičnikika ierosināja "neminēt konkrētu valsti, konkrētas vietas, kur notiek darbỉba". ${ }^{102}$ Līdzīga situācija atkārtojās 1984. gada 29. augustā, kad CT aicināja filmai "Pēdējā vizìte" izdarīt vairākus montāžas labojumus, tostarp "izgriezt [oriğ. iskljuchit'] karogu tuvplānus (aina uz 
jahtas)". ${ }^{103}$ Šìs darbības norāda uz nepieciešamību kinematogrāfistiem tikai radīt Rietumu šḳietamību, kas nekādā veidā nevar traucēt norisēm starptautiskajā politikā. Turpretī tās ietekme uz kinematogrāfiju bija pretēja - 80. gados notikumi starptautiskajā arēnā kḷuva par iemeslu, ar ko varēja pamatot tādu vai citādu sižeta risinājumu Rīgas kinostudijas veidotā filmā. Tā, piemēram, filmas "Pēdējā reportāža” (5. att.) veidošanas laikā, 1986. gada 18. martā, CT aicināja kinostudiju "atgriezties pie literārā scenārija varianta, kur Lobenšteins kḷūst par neofašistu upuri. Šāds nobeigums ir pārliecinošāks, nemot verrā nesenos notikumus pasaule" ${ }^{104}$

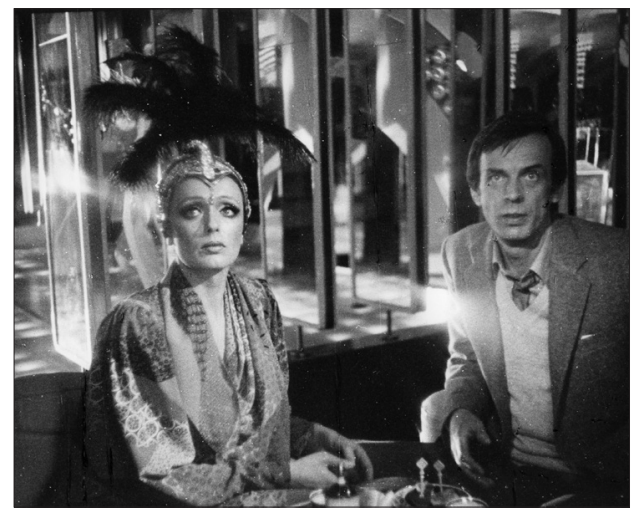

5. att. Filmas “Pēdējā reportāža” (režisore Dzidra Ritenberga) epizode. Birgita (Reginna Razuma) un galvenais varonis - žurnālists Lobenšteins (Georgijs Taratorkins). 1986.

Avots: Rīgas Kino muzejs, RKM 187.

Fig. 5. A scene from the film Pēdējā reportāža (director Dzidra Ritenberga). From Left: Birgit, played by Regina Razuma and the main character, journalist Lobenstein, played by Georgij Taratorkin. 1986.

Source: Riga Film Museum collection, RKM 187.

Tiešu ietekmi uz filmu veidošanu atstāja arī PSKP CK ǵnenerālsekretāra M. Gorbačova 1985. gada 16. maijā sāktā "pretalkohola kampaņa”. Tā paša gada 1. oktobrī, filmas "Pēdējā reportāža" tapšanas laikā, RKS
Scenāriju redkolēgijas galvenā redaktore L. Brīdaka saṇēma CT vēstuli, kura nosūtīta, lai "izvairìtos no nesaprašanās nākotnē":

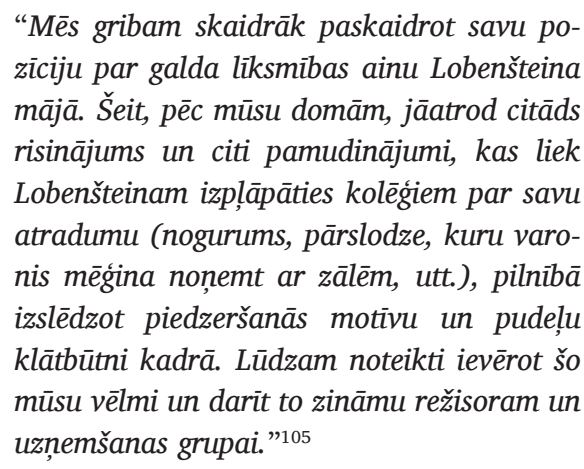

Izvērstā norāde par iedzeršanas ainu skaidri liecina par veidu, kādā PSKP CK direktīvais lēmums "Par žūpības un alkoholisma novēršanas pasākumiem" ietekmēja kinematogrāfiju. Lēmums paredzēja "nepiel̦aut, lai teātros, kino, televizizijas un radio pārraidēs, kā arī mākslas darbos iekḷūtu moti$v i$, kas propagande iedzeršanas un dzires". ${ }^{106}$

Kinokritikas vērtējumos par kontrpropagandas filmām sākotnēji bija vērojamas "žanra" attīstības iezīmes, proti, tika akcentēta pirmo ekranizāciju literārā ievirze, mākslinieciskais nozīmīgums, pasvītrota "kontrpropagandas" funkcija (lai gan arī šeit līdz 80. gadiem nesaukta tādā vārdā) un cildināta filmu politiskā nozīmība. Daudzi kritikas apgalvojumi pat vārds vārdā atkārtoja RKS iekšējās diskusijās izteiktos vērtējumus. Vēlāk, 80. gadu pirmajā pusē, filmu veidotāju un kritikas ceḷi šḳīrās: padomju Latvijas kinokritika filmas sāka vērtēt vienīgi "nacionālās" kinomākslas kontekstā, attiecinot uz filmām stingrus mākslinieciski estētiskos kritērijus. Kritika nerespektēja CT kā pasūtītāja būtisko ietekmi uz filmu sniegumu un nereti vērtēja šīs grupas filmas ar labāko studijas filmu mērauklu. To apliecina pieaugošā "kontrpropagandas" filmu kritika, kas bija ne tik daudz atkarīga no šo filmu shematiskuma vai "žanriskās" 
bezjēdzības, cik no kvalitatīvu mākslas filmu trūkuma "nacionālajā" kinomākslā kopumā. Šāda vienota konteksta apstākḷ os bija viegli skatīt "kontrpropagandas" filmas kā darbus, kuriem tiek "lieki" tērēti kinostudijas intelektuālie resursi. Vienlaikus, sagaidīdama daudz augstāka līmeña "kontrpropagandu", kritika neapzinājās vai ignorēja reālos apstākḷus, kādos bija jāstrādā RKS, veidojot šāda veida filmas.

\section{ATSAUCES UN SKAIDROJUMI}

${ }^{1}$ Raksta pamatā ir autora maǵistra darbs "Kontrpropaganda PSRS kinomākslā 1970. un 1980. gados: Rīgas kinostudijas mākslas filmas par Rietumu sabiedrību" (Latvijas Universitāte, 2016), darba zinātniskais vadītājs: docents Jānis Keruss.

${ }^{2}$ KRISTīne MATīsA. Vecās labās... 50 latviešu kinoklasikas spožākās pērles. Rīga 2005.

${ }^{3}$ INGA PĒRKONE (zin. red.). Inscenējumu realitāte. Latvijas aktierkino vēsture. Rīga 2011.

${ }^{4}$ Sari Autio-Sarasmo, Katalin Miklóssy (ed.). Reassessing Cold War Europe. Abingdon, New York 2011, p. 2.

${ }^{5}$ Tony SHAw. The Politics of Cold War Culture. In: Journal of Cold War Studies 3, Fall 2001, No. 3, p. 59.

${ }^{6}$ Ibidem, p. 75.

${ }^{7}$ Eva EglĀJA-Kristsone. Dzelzsgriezēji. Latvijas un trimdas rakstnieku kontakti. Rīga 2013, 90. lpp.

${ }^{8}$ PĒTERIS JĒrĀNS (red.). Politiskā enciklopēdija. Rīga 1987, 562. lpp.

${ }^{9}$ PĒRKone, Inscenējumu realitāte, 410. lpp.

${ }^{10}$ MiKe BOWKeR. Brezhnev and Superpower Relations. In: EDWIN BACON, MARK SANDLE (eds.). Brezhnev Reconsidered. Hampshire, New York 2002, p. 90.

${ }^{11}$ BORISS SOKOLOVS. Leonīds Brežņevs. Zelta laikmets. Rīga 2008, 122. lpp.

12 BOWKER, Brezhnev and Superpower Relations, pp. 91-92.

${ }^{13}$ TONIJS DŽADS. Pēc kara. Rīga 2007, 561. lpp.

${ }^{14}$ HENRIJS KisindŽERs. Diplomātija. Rīga 2001, 794. lpp.

${ }^{15}$ RODGER KANET (ed.). The Soviet Union, Eastern Europe and the Third World. Cambridge [et al.]: Cambridge University Press, 1987. p. 75.

${ }^{16}$ Ibidem, p. 75.

${ }^{17}$ MAREK Mill. The Communist Party's Fight against "Bourgeois Television” 1968-1988. In: TõNU TANNBERG (ed.). Behind the Iron Curtain. Soviet Estonia in the Era of the Cold War. Frankfurt am Main [et al.] 2015, p. 326.

${ }^{18}$ KANET, The Soviet Union, Eastern Europe and the Third World, p. 75.

${ }^{19}$ Ibidem, p. 76.

${ }^{20}$ BOWKER, Brezhnev and Superpower Relation, p. 97.

${ }^{21}$ KANET, The Soviet Union, Eastern Europe and the Third World, p. 76.

${ }^{22}$ V Central'nom Komitete KPSS. In: Pravda, 06.05.1979. s. 1.

${ }^{23}$ Ibidem.

${ }^{24}$ KANET, The Soviet Union, Eastern Europe and the Third World, p. 76.

${ }^{25}$ PĒRKONE, Inscenējumu realitāte, 84. lpp.

${ }^{26}$ Ibidem, 96. lpp.

${ }^{27}$ Ibidem, 97. lpp.

${ }^{28}$ Ibidem, 100. lpp. 
${ }^{29}$ PĒrRone, Inscenējumu realitāte, 90. lpp.

${ }^{30}$ AUSTRA Zīle. Sarunas aiz kadra. Stāsti par desmitās mūzas kalpiem. Rīga 2005, 41.-42. lpp.

${ }^{31}$ PĒTERIS ZeILE. No ieceres līdz filmai. In: Cīṇa, 16.07.1986., 4. lpp.

32 PĒRKone, Inscenējumu realitāte, 98. lpp.

${ }^{33}$ Ibidem.

${ }^{34}$ Konstantin SoKolov. Hudozhestvennaja kul'tura i vlast' v poststalinskoj Rossii: sojuz i bor'ba (1953-1985 gg.). Sankt-Peterburg 2007, s. 34.

${ }^{35}$ PĒRKone, Inscenējumu realitāte, 98. lpp.

${ }^{36}$ ELMĀRS RIEKSTIN̦Š (red.). Padomju Latvijas kinomāksla. Rīga 1989, 271. lpp.

37 PĒRKone, Inscenējumu realitāte, 97. lpp.

${ }^{38}$ VAleriJ GolovsKoJ. Mezhdu ottepel'ju i glasnost'ju. Kinematograf 70-h. Moskva 2004, s. 99.

${ }^{39}$ IGOR' KOKAREV. Rossijskij kinematogaf: mezhdu proshlym i budushhim. Moskva 2001, s. 30.

${ }^{40}$ GolovskoJ, Mezhdu ottepel'ju i glasnost'ju, s. 100.

${ }^{41}$ A. JuRĒVIČs. Piecu dienu darba nedēl̦a un mēs. In: Padomju Jaunatne, 26.05.1967., 2. lpp.

${ }^{42}$ KoKAREV, Rossijskij kinematogaf, s. 30.

${ }^{43}$ MARINA KosinOvA. Parametry krizisa organizacionno-jekonomicheskoj sistemy sovetskogo kinematografa. In: ANDREJ SHEMJAKin, JuliJA Miheeva (red.). Posle Ottepeli. Kinematograf 70-h. Moskva 2008, s. 66.

${ }^{44}$ Ibidem.

${ }^{45}$ KosinOVA, Parametry krizisa organizacionno-jekonomicheskoj sistemy sovetskogo kinematografa, s. 66.

${ }^{46}$ Ibidem, s. 67.

${ }^{47}$ Ibidem.

${ }^{48}$ Ibidem, s. 68.

${ }^{49}$ GolovskoJ, Mezhdu ottepel'ju i glasnost'ju, s. 100.

${ }^{50}$ Ibidem.

${ }^{51}$ Ibidem.

${ }^{52}$ PĒRKONE, Inscenējumu realitāte, 216. lpp.

${ }^{53}$ Ibidem, 220. lpp.

${ }^{54}$ ZeILE, No ieceres līdz filmai, 4. lpp.

${ }^{55}$ PĒRKONE, Inscenējumu realitāte, 224. lpp.

${ }^{56}$ Ibidem.

${ }^{57}$ Ibidem, 216. lpp.

${ }^{58}$ Ibidem, 217. lpp.

${ }^{59}$ Ibidem. 218. lpp

${ }^{60}$ Ibidem, 219. lpp.

${ }^{61}$ Julija Mineeva. Neser'eznoe kino. In: Shemjakin, Mineeva, Posle Ottepeli, s. 287.

62 Ibidem, s. 74.

${ }^{63}$ Ibidem, s. 75.

64 Julija Homjakova. Knizhnoe kino. In: Shemjakin, Mineeva, Posle Ottepeli, s. 79.

${ }^{65}$ Ibidem, s. 80.

${ }^{66}$ Ibidem, s. 79.

${ }^{67}$ Ibidem, s. 80.

${ }^{68}$ Ibidem. 
69 Julija Homjakova. Knizhnoe kino. In: Shemjakin, Mineeva, Posle Ottepeli, s. 109.

${ }^{70}$ Jēdzieni "industriāls" un "filmu ražošana" padomju kinematogrāfijas kontekstā izriet no kinostudiju iekḷaušanas padomju plānveida komandekonomikā, kur studijas, līdzīgi rūpniecības uzņēmumiem, pildīja tām uzliktus filmu ražošanas plānus.

${ }^{71}$ PĒrkone, Inscenējumu realitāte, 83. lpp.

${ }^{72}$ Ibidem, 84.-85. lpp.

${ }^{73}$ Ibidem, 86. lpp.

${ }^{74}$ Ibidem, 87. lpp.

${ }^{75}$ Miks Zvirbulis. Ievadvārdi bez virsraksta. In: SARMĪTE ĒLERTE (sast.). Kino pasaule. Rīga 1987, 4. lpp.

${ }^{76}$ PĒRKone, Inscenējumu realitāte, 224. lpp.

77 ZEILE, No ieceres līdz filmai, 4. lpp. Viens no raksturīga "klasiska" padomju detektīva piemēriem Rīgas kinostudijā ir Aloiza Brenča filma "Šahs briljantu karalienei” (1973).

${ }^{78}$ Kelly Catriona. Period zapoya: Film-Making in Brezhnev-Era Leningrad. Pieejams: https://www. nlobooks.ru/magazines/novoe_literaturnoe_obozrenie/152/article/20023/ (skatīts 11.05.2019.).

${ }^{79}$ Rīgas kinostudijas Mākslas padomes (turpmāk - RKS MP) 20.11.1985 sēdes protokols. Latvijas Nacionālais arhīvs, Latvijas Valsts arhīvs, Rīga (turpmāk - LNA LVA), 416-4-342, 52. lp.

${ }^{80}$ RKS MP 01.08.1986 sēdes protokols. Ibidem, 76. lp.

${ }^{81}$ PSRS Valsts televīzijas un radioraidījumu komitejas radošās apvienības "Ekran" 01.03.1982. slēdziens par televīzijas filmas "Mirāža" literāro scenāriju. Ibidem, 416-4-242, 242. lp.

${ }^{82}$ RKS MP 09.01.1976. sēdes protokols. Ibidem, 416-4-98, 81. lp.

${ }^{83}$ Rīgas kinostudijas Scenāriju redakcijas kolēǵijas (turpmāk - RKS SRK) 07.12.1978. sēdes protokols. Ibidem, 416-4-122, 105. lp.

${ }^{84}$ RKS MP 07.12.1982. sēdes protokols. Ibidem, 416-4-242, 270. lp.

${ }^{85}$ RKS MP 07.12.1982. sēdes protokols. Ibidem, 269. lp.

${ }^{86}$ RKS MP 07.06.1983. sēdes protokols. Ibidem, 416-4-312, 8. lp.

${ }^{87}$ PSRS Valsts televīzijas un radioraidījumu komitejas priekšsēdētāja Sergeja Lapina (Sergey Georgiyevich Lapin) 16.05.1980. vēstule. Ibidem, 416-4-122, 248. lp.

${ }^{88}$ RKS MP 09.01.1976. sēdes protokols. Ibidem, 416-4-98, 81. lp.

${ }^{89}$ RKS MP 09.01.1976. sēdes protokols. Ibidem, 100. lp.

${ }^{90}$ VIESTURS Avots. Gribētos uzzināt vairāk par cilvēkiem. In: Literatūra un Māksla, 19.07.1984., 6. lpp.

${ }^{91}$ RKS MP 12.03.1976. sēdes protokols. LNA LVA, 416-4-98, 65. lp.

92 RKS MP 28.05.1976. sēdes protokols. Ibidem, 45. lp.

${ }^{93}$ RKS MP 28.05.1976. sēdes protokols. Ibidem, 46. lp.

${ }^{94}$ Ibidem.

${ }^{95}$ RKS MP 17.06.1982. sēdes protokols. Ibidem, 416-4-242, 263. lp.

${ }^{96}$ RKS MP 17.06.1982. sēdes protokols. Ibidem, 264. lp.

${ }^{97}$ RKS MP 29.03.1984. sēdes protokols. Ibidem, 416-4-312, 198. lp.

${ }^{98}$ RKS MP 29.03.1984. sēdes protokols. Ibidem.

${ }^{99}$ Ibidem.

${ }^{100}$ RKS MP 20.11.1985. sēdes protokols. Ibidem, 416-4-342, 51. lp.

${ }^{101}$ RKS SRK 07.06.1983. sēdes protokols. Ibidem, 416-4-312, 8. lp.

${ }^{102}$ RKS SRK 12.04.1979. sēdes protokols. Ibidem, 416-4-122, 221. lp.

${ }^{103}$ PSRS Valsts televĩzijas un radioraidījumu komitejas radošās apvienības "Ekran" 29.08.1984. slēdziens par filmu "Pēdējā vizìte" (filmas pieṇemšanas akta pielikums). Ibidem, 416-4-312, 213. lp. 
${ }^{104}$ PSRS Valsts televīzijas un radioraidijumu komitejas radošās apvienības "Ekran" 18.03.1986. slēdziens par filmu "Pēdējā reportāža". Ibidem, 416-4-342, 69. lp.

${ }^{105}$ PSRS Valsts televizzijas un radioraidījumu komitejas radošās apvienības "Ekran” 01.10.1985. vēstule. Ibidem, 47. lp.

${ }^{106}$ Par žūpības un alkoholisma novēršanas pasākumiem. In: Cīṇa, 17.05.1985., 1. lpp.

\section{SUMMARY}

The Cold War was partly represented by using certain words and imagery. During the 40-year-long conflict between the West and the Soviet bloc, at the very centre of attention was the multi-faceted propaganda on various levels - mutually employed weapons of information warfare were music, art of dance, cinematography, design, creation and dissemination of words and characters. Western scholars argue that cultural activities had a pivotal role in the ideological competition and they have shaped the understanding about the Cold War for many.

During the 1970s and 1980s, Riga Film Studio produced a series of specific films, i.e. several television film series set entirely in 'capitalist West'. They had distinct features that were not present in other Soviet films of the same period, e.g., scenarios based on literary works by foreign authors, action that takes place in the 'Western countries' and 'Western' characters. An important difference prevailed regarding the aim of the films along with the entertainment they had to serve a purpose of counter-propaganda - to discredit the Western way of life according to the Soviet ideological principles. Despite the fact that such pieces were also produced by other Soviet studios, only Riga Film Studio made a significant amount of such films.

The first was a two-episode film Nāve zem buras produced in 1976 (directed by Ada Neretniece, written by Viktors Lorencs). It was based on the novel "Death Under Sail" (1932) by Charles Percy Snow and its cinematographic adaption was commended by Lorencs. In 1979, after a commission by the Central Television, the two-episode film Nepabeigtās vakarinas (directed by Jānis Streičs, written by - Alvis Lapiņš) was made. The film was based on the crime novel Polis, polis, potatismos! (1970) by Per Wahlöö and Maj Sjöwall. After a proposal by Aloizs Brenčs, the three-episode film Mirāža (directed by Aloizs Brenčs, written by Alvis Lapiņš) was produced. The film was an adaption of the novel "The World in My Pocket" (1959) by James Hadley Chase. The film is widely regarded as the most popular and successful counter-propaganda piece produced by the RFS. A screen adaptation of the novelette "The Washington Party Murder" (1964) - oneepisode Pédējā vizite - was shot in 1984 (directed by Ada Neretniece, written by Irina Čerevičnika). The last film in the category was the two-episode film Pēdeja reportāža (directed by Dzidra Ritenberga, written by Jurijs Kal,ěčuks) based on Gert Prokop's novel Der Tod des Reporters (1973).

The Riga Film Studio's television film series about Western society was a rather peculiar Cold War phenomenon that embodied a mixture of international politics, fundamental soviet ideological principles and tendencies of cinematography. Although the films were often isolated initiatives proposed by particular authors and later on developed as an individual (yet collectively modified and censored) cultural fact, the conditions allowing such films to see daylight were influenced by a variety of multi-layered factors - from individual beliefs to the processes in international politics. 